\title{
David versus Goliath in the food policy space
}

\author{
Review by Elizabeth Morgan* \\ Macquarie University
}

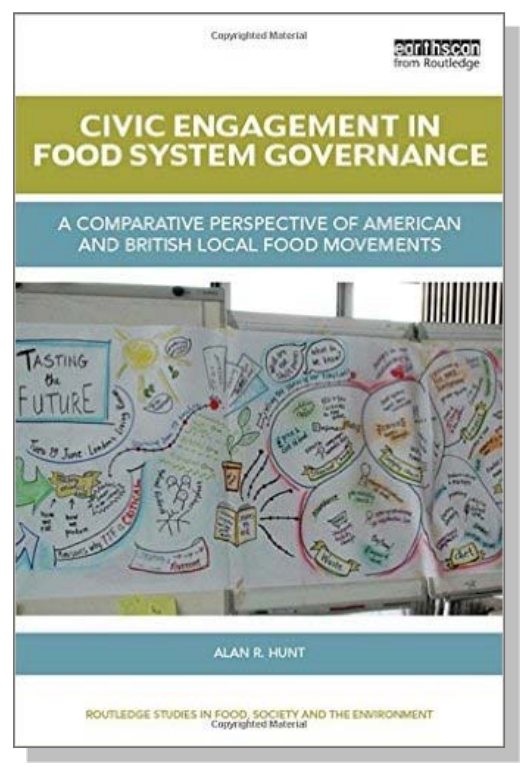

Review of Civic Engagement in Food Systems Governance: A Comparative Perspective on American and British Local Food Movements, by Alan R. Hunt. (2015). Published by Routledge. Available as hardcover, Kindle eBook, and iBook; 276 pages. Publisher's website: https://www.routledge.com/books/details/9781138888432

Submitted September 27, 2016 / Published online December 4, 2016

Citation: Morgan, E. (2016). David versus Goliath in the food policy space [Book review]. Journal of Agriculture, Food Systems, and Community Development, 7(1), 139-140. http://dx.doi.org/10.5304/jafscd.2016.071.010

Copyright (C) 2016 by New Leaf Associates, Inc.

$\mathrm{I}^{\mathrm{n}}$ $\mathrm{n}$ the food studies field, it is uncommon to encounter a local food/alternative food movement practitioner who is also an academic. Alan R. Hunt is one of these rare birds. He runs a consultancy business, Local Food Strategies, working from his parents' farm in Hampton, New Jersey, after completing a Ph.D. in rural development in northern England in 2013. Hunt's interest in how producers and consumers could breathe new life into local food systems was piqued by his experience of trying to preserve the family property as a sustainable, working farm in the face of

* Elizabeth Morgan is a Ph.D. candidate in the Department of Geography and Planning at Macquarie University in Sydney, Australia. Her research is on the role of local government in food security, with case studies on two local government authorities in Western Sydney. She can be contacted at elizabeth.morgan@mq.edu.au. political and economic pressures, such as the U.S. farm bill and urban encroachment on peri-urban land. The farmer in Hunt is acutely aware of the unintended consequences of ostensibly wellmeaning laws and wondered what difference it could make if stewards of the land were tapped for their unique, local knowledge. His research question in Civic Engagement in Food Systems Governance was: "How have stakeholders been included in the policy process, and has the policy process responded to their interests and concerns?" (p. xiii, emphasis in original). These are the crucially important questions that Hunt explores in his comparison of local food advocacy organizations in Britain and the United States.

In essence, Civic Engagement in Food Systems Governance is a treatise on the battle facing social movement organizations (SMOs) in the food system space- the Davids versus the hegemonic, 
policy-making Goliaths (Belasco, 2012). Given that "it has always been somewhat ironic that ideas about collective action have been so influenced by thinkers in the United States - to many the home of individualism" (Edwards, 2011, p. 482), the absence of a theoretical framework on SMOs to set up the comparative case studies is regrettable. One would expect mention of Jurgen Habermas's theories on social movements and activism, perhaps, or U.S. sociologist Theda Skocpol's work on civic engagement in American politics. The issue of social movements is briefly dealt with in a tad more than a page, and does little to whet the appetite for the interesting case studies to come. The irony noted by Edwards is particularly worth exploring conceptually, especially because it is borne out in Hunt's findings and conclusions.

The book opens with an historical tracing of food policies and food movements in Britain and the United States (1991-2012 and 1976-2012, respectively). Significant differences between the two countries quickly emerge: local food in national American policy (Chapter 2) is described as "increasing inclusion, increasing policy success" (p. 22), whereas local food in national English policy (Chapter 3) is characterized as "policy decline with increased contention" (p. 59). This is not what Hunt, nor the reader, expects, and it is an exciting revelation.

Chapters 4 and 5 are the case studies proper, and can be summarized by the respective chapters' subheadings: "The co-option of local food policy by environmental interest groups" in England, and "Overcoming barriers to policy change due to civil society coordination failure" in the United Statesrather cumbersome ways of saying that American activists are good at putting aside their differences, are more socially just and inclusive, and are more successful at influencing policy than their British counterparts. What is intriguing in these chapters is the insider's view of how these advocacy groups organize and operate. The "thick description" that Hunt distills from his voluminous research material will be of great interest to those in the business of advocating to government on any policy, but the reader does have to wade through rather a lot of text peppered with dozens of acronyms to unveil the narrative.
The analysis and conclusions in Chapters 6 and 7- "Making space for collaboration in the food system; Three practices for overcoming exclusion" and "Toward a theory of food systems practice"are as nebulous as their titles. There is a weary tone where one would expect a thrilling crescendo: "Look what I've found!" Instead, the very last sentence of the final chapter's concluding section reads: "Civic engagement is a cornerstone of food system governance." Routledge editors, take note.

Hunt's doctoral thesis and book the share the exact same title, and the latter followed the former by less than two years. This suggests a quick reworking of the thesis into a book, a supposition that is lent some weight by, for example, a references section that runs to 43 pages and about 850 entries—-the first an enigmatic "7 U.S.C. $\int 1991$ (11)(b)," and also by chapter titles with the opening words: "This chapter focuses ..."; "This chapter directly contrasts ..."; "The study profiles....” To this reviewer, this is "thesis speak," not "book speak." It is a pity because the originality of Hunt's contribution to the food policy discourse is diminished by the pedestrian presentation of the material and an absence of pizzazz about the findings, which are significant and worth shouting about. Food activists have much to glean from this book, but my hunch is that it will predominantly circulate in academic and policymaking circles, by virtue of its price alone ( $f 85$ hardback, US $\$ 110$ ). To use a food analogy, there is plenty of meat in Hunt's research, but rather like a large pan of paella, one has to sift through a lot of plain old rice to find the protein-rich nourishment.

\section{References}

Belasco, W. (2012). Food and social movements. In J. M. Pilcher (Ed.), The Oxford handbook of food history (pp. 481-498). New York, USA, and Oxford, UK: Oxford University Press. http://dx.doi.org/10. 1093/oxfordhb/9780199729937.013.0027

Edwards, M. (2011). Civil society as a necessary and necessarily contested idea. In M. Edwards (Ed.), The Oxford handbook of civil society (pp. 1-13). http://dx.doi.org/10.1093/oxfordhb/9780195398 $\underline{571.013 .0038}$ 